\title{
クリーンルーム気流の均一性に関する研究 AIRFLOW UNIFORMITY IN UNIDIRECTIONAL FLOW CLEANROOMS
}

\author{
謝 国 平*, 西 岡 利 晃** \\ Guoping XIE and Toshiaki NISHIOKA
}

\begin{abstract}
In unidirectional flow cleanrooms, it is important to form a uniform airflow distribution to exhaust quickly contaminants generated indoors. The uniformity of airflow distribution in a cleanroom has been studied as function of the height of plenum chamber and the velocity of flow introduced into the chamber.

The influences of the height of the plenum chamber and the velocity of the flow introduced into the chamber on the airflow uniformity are investigated by experiment. In addition, a numerical simulation method to predict the flow uniformity is proposed by taking into account the characteristics of filter's pressure loss. The calculation domain in this study includes not only the cleanroom but the plenum chamber and the exhaust chamber. The validity of the numerical method is also verified by comparing the simulation results with the experimental results. Finally, the method is used to obtain an appropriate height of the plenum chamber and an appropriate velocity of the flow introduced into the chamber.
\end{abstract}

Keywords: unidirectional flow cleanroom, uniformity of airflow distribution, model, experiment, numerical simulation

整流型クリーンルーム、気流の均一性、模型、実験、数值解析

\section{1.はじめに}

本研究では、天井チャンバ方式の整流型クリーンルー ムの設計に資することを目的として、室内に均一な気流 分布を得るための諸条件を実験および数值解析により検 討した。

垂直整流型クリーンルームにおいて設計清浄度を維持 するためには、発生した污染物質を室外へ速やかに排除 し、製品への污染を未然に防止することが必要である。 このためクリーンルームの設計においては室内の気流速 度を均一化し、風向のそろった流れを形成するような構 造が要求される。特に半導体デバイスの製造ラインとし て使用するクリーンルームでは、室内の気流のばらつき により生じる偏流などが、隣接する製造プロセスへのク ロスコンタミネーションの原因となる。このため、 4 Mbit以上のDRAM(Dynamic Random Access Memory)製造用 クリーンルームでは、空間的な風速のばらつきが $10 \%$ 以 内となるような気流分布が経験的に要求されている。

クリーンルームにおける偏流の発生要因には、天井お よび床下チャンバでのダクト配置の偏りや障害物による ネック風速の発生、室内に設置する設備などのレイアウ 卜の偏りなどが考えられる。室内全体にわたって均一な
気流分布を得るには、まずフィル夕からの吹出し風速お よび床面でのリターン風速を均一化することが必要であ る。なかでも天井チャンバについては、その後流側であ るクリーンルーム内の気流状態に大きく影響するものと 考えられ、チャンバ構造や運転条件之風速の均一性之の 関係を明確化することがクリーンルーム設計において重 要である。

気流の均一性に関しては、天井チャンバを連続分配タ クトと仮定してクリーンルーム内の気流分布を演算する もの3) と、数值解析手法を用いて流れの連続方程式および 運動量方程式を解くことにより室内の流れ場を求めるも $の^{122) 4}$ のつの考元方がある。前者は、ベルヌーイの定理 に基づいたもので、計算が簡単なため、ダクトおよび チャンバ高さの目安を決めるには用いられることがある。 しかし、この方法は、流れ場の 1 次元解析（疑似的に2次 元）しかできないこと、給気ダクトからの流れによる誘 引現象を考慮できないこと、室内に製造装置が設置され た場合に対応できないこと、などの問題点が指摘される。 これに対して、後者の数值解析は、計算がやや複雑であ るが、流れ場の3次元解析が可能で、より緻密な情報（局 所的な風速、風向も含む）を得ることができる。また、
* (株) 大林組技術研究所 研究員 $\cdot$ 工博

** 大阪市立大学建築学科 助教授 $\cdot$ 工博
Research Engineer, Technical Research Institute, Obayashi Corp., Dr. Eng.

Assoc. Prof., Dept. of Arch. \& Bldg. Eng., Osaka City Univ., Dr. Eng 


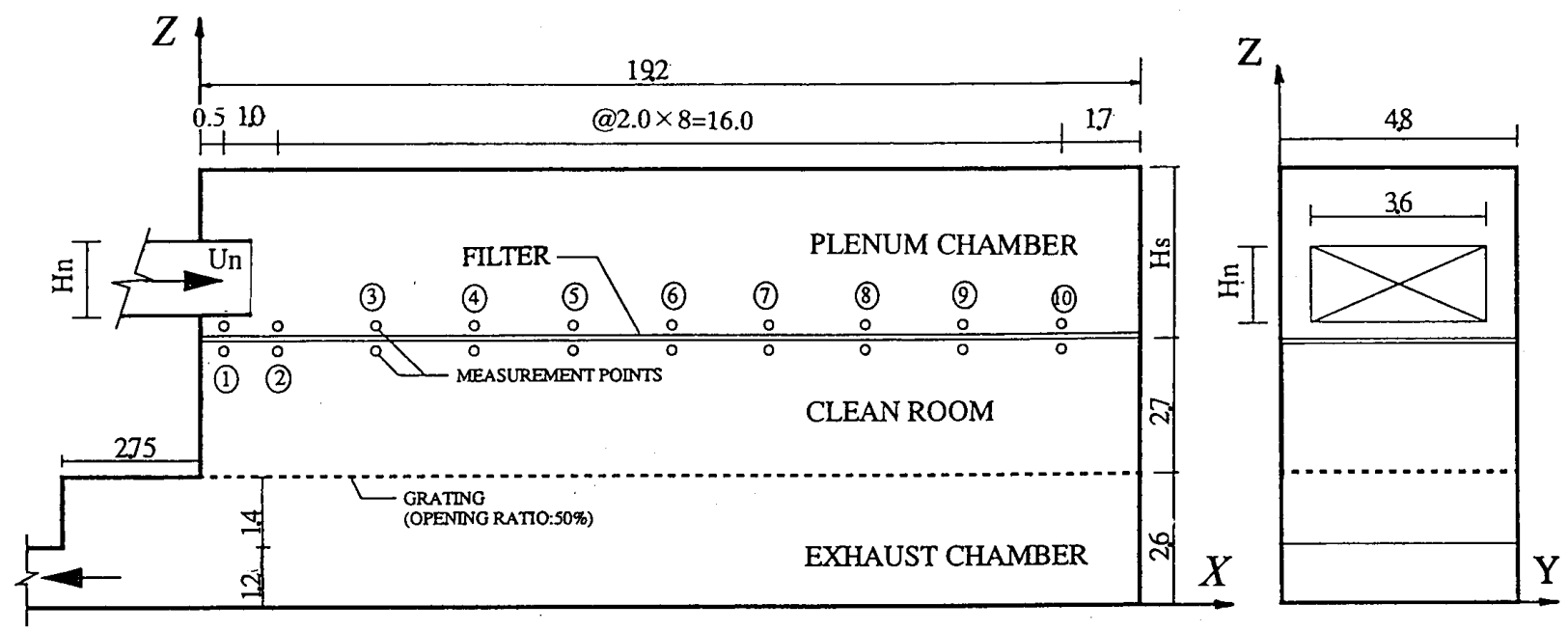

図1 天井チャンバ方式のクリーンルームの断面

装置の配置が流れ場への影響も解析できる。

数值解析手法を用いた研究例としては、前田・田中ら 1)2)およびSadjadi ら4)の報告がある。前田・田中らは、 フィル夕面からの気流速度が均一であると仮定し、床面 の開口率や室の長さによる風向の変化について検討を 行っている。しかし、対象領域としてフィル夕よりも上 流側の系を考慮しておらず、天井チャンバの構造などに 起因する風速分布のばらつきについては検討していない。 Sadjadiらは、井チャンバの高さと気流のばらつきとの 関係について、数値解析を行っているが、解析結果につ いての実験的な検証が十分には行われておらず、予測手 法の有効性については検討を必要としている。

そこで本研究では、まず天井チャンバの高さおよび チャンバへの吹出し風速がクリーンルーム内気流の均一 性に及ぼす影響について実験的な検討を行った。また フィルタの压力損失特性を考虑した気流の数值解析手法 を提案し、実験結果との比較により本手法の有効性を確 認した。さらに、提案した数值解析手法を用いてチャン バ構造や吹出し風速の適正化を試みた。以下、これらの 結果を報告する。

\section{2. 気流の均一性に関する実験}

本研究で対象とする天井チャンバ方式クリーンルーム の断面を図1に示す。本クリーンルームではその上流側に 天井チャンバ、下流側に床下チャンバを有し、フィル夕 面から床面へと下降流を形成する。天井チャンバ（高さ Hs:1.95 3.37m) への給気は、チャンバの片側に取付けた ノズル（高さHn:0.5〜 1.5m）により行う。クリーンルー ムそのものの寸法は $19.2 \times 4.8 \times 2.7 \mathrm{~m}$ とした。

実験は、縮尺 $1 / 10$ の模型を用いて行った。模型に用い たフィルタについては、実用風速範囲内で実際のHEPA フィルタと同等の特性を有する疑似フィル夕を製作した。

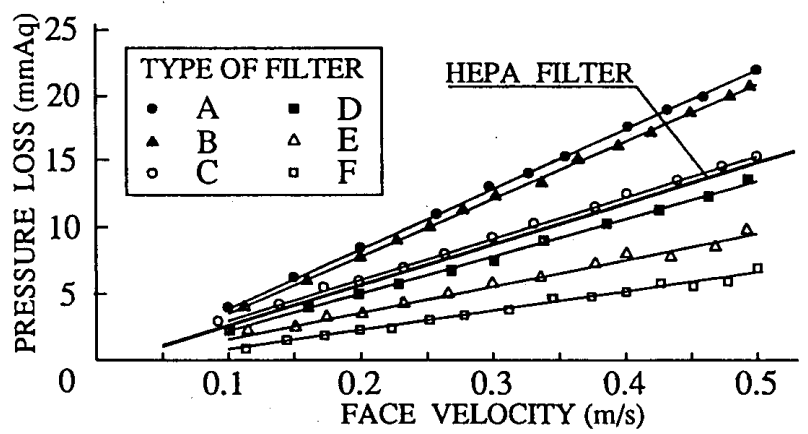

図2 疑似フィルタの面風速と圧力損失との関係

図2に疑似フィルタの王力損失と面風速之の関係を示す。 図中の疑似フィル夕Cは、面風速0.1 0.5 $/ \mathrm{s}$ の範囲で、圧 力損失と面風速之は直線関係にあり、また直線の勾配が HEPAフィルタとほぼ一致している。

\section{1 実験方法}

圧力損失が生じる流体現象を模型実験で検討する際に、 王力損失に関する相似条件は次式で与えられる。

$$
n_{c} \cdot n_{u}{ }^{n-2}=1
$$

ここで、 $\mathrm{n}_{\mathrm{c}}$ : 模型の抵抗係数之実物の抵抗係数の比

$\mathrm{n}_{\mathrm{u}}:$ 模型の風速之実物の風速の比

$\mathrm{n}$ : 圧損之風速の関係を表わすべキ指数

本研究では、図2に示すように、 $\mathrm{n}=1$ 。また、模型に用 いた疑似フィルタと実物では抵抗係数が等しいため、 $\mathrm{n}_{\mathrm{c}}=1$ となる。したがって、 $\mathrm{n}_{\mathrm{u}}=1$ でなければならない。即 ち、模型実験では実風速を用いることが必要条件である。

一方、レイノルズ数が十分大きな流れの問題では、現 象の相似性からも実風速を用いて実験条件を設定する方 法がしばしば用いられる。これに関する詳細な検討は勝 
田・土屋5)、村上・加藤ら6)によって行われている。本研 究で対象とするクリーンルームではレイノルズ数が $10^{5}$ $10^{6}$ と大きい。

以上のことから、本実験では実風速を使用した。

実験には、10台の校正済みの差压計(YAMAMOTO ELECTRIC WORKS Co., MANOSTAR GAGE, WO-80)を用 いて、図1に示した(1)〜价の測定点におけるフィルタ上流 㑡と下流側の差压を同時に測定した。

測定点のY方向での位置については、サンプリングパ イプの気流に及ぼす影響を抑えるため、天井チャンバ内 でのパイプをできるだけ短くすることが望ましい。また、 模型の壁面による気流分布の影響を受けないよう、ある 程度壁面から離れる必要がある。そこで予借実験を行い、 図3に示すように、壁面の影響を受けない範囲で最もパイ プが短くなる $1 \mathrm{~cm}$ の位置に測定点を設定した。Z方向につ いては、それぞれフィルタの上面と下面から $2 \mathrm{~cm} の$ 位置と した。

図2に示したように、フィルタの差压と面風速とは比例 関係にあることから、本研究では天井面での差圧分布を 測定することにり、フィルタ面での風速分布の均一性を 評価することとした。

実験条件は次のとおりである(以下、風速、風量および 寸法については、実物に换算して表わす)。

1) ファンの送風量 : $9.2 、 27.6 、 46.1 \mathrm{~m}^{3} / \mathrm{s}$ の3種類。これ に対応したフィル夕直下の平均風速（風量／天井面積） はそれぞれ0.1、0.3、0.5 m/sटなる。

2) 天井チャンバの高さHs : $1.95 、 3.37 \mathrm{~m} の 2$ 種類。

3) 給気ノズルの高さHn : 0.5、1.5mの 2 種類。ノズル高 さの変更によりチャンバへの吹出し風速を変化させた。

\section{2 実験結果および考察}

天井チャンバの高さを $3.37 \mathrm{~m} 、$ 給気ノズルの高さを $1.5 \mathrm{~m}$ としたときの差圧分布を図4に示す。ここでは供給風量を 46.1、27.6、9.2 $\mathrm{m}^{3} / \mathrm{s}$ (ノズルからの吹出し風速はそれぞれ 8.6、5.1、1.7m/s)の3段階に変化させた場合について併記 した。いずれの場合もSD/MEAN(標準偏差/平均値)は $5 \%$ 以下となっている。

図5は給気ノズルからの吹出し風速を前述のケースと同 様に設定し、天井チャンバの高さを1.95mに下げた場合で ある。図4の場合に比へて SD/MEANが大きくなっており、 特に供給風量が大きい場合には、ノズル付近での差压が 平均値より小さくなっていることがわかる。

天井チャンバの高さを $1.95 \mathrm{~m}$ に設定したまま, さらに ノズル高さを $0.5 \mathrm{~m}$ として吹出し風速を増大させた場合の 差压分布を図6に示す。風量 46.1 および $27.6 \mathrm{~m}^{3} / \mathrm{s}$ （ノズル の吹出し風速はそれぞれ25.7、15.4m/s）のとき、差压分 布には大きなばらつきを生じており、SD/MEAN はそれ

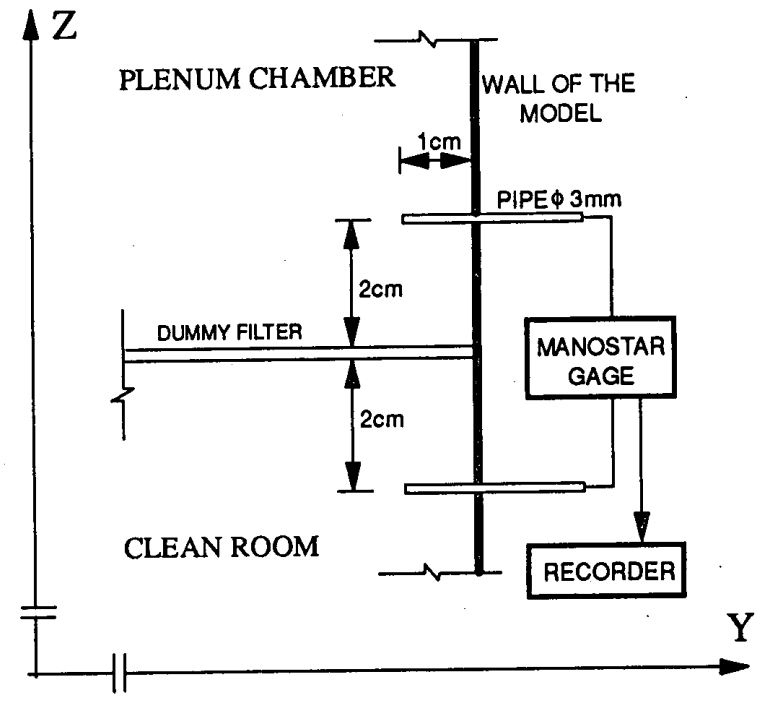

図3 差压測定の概要

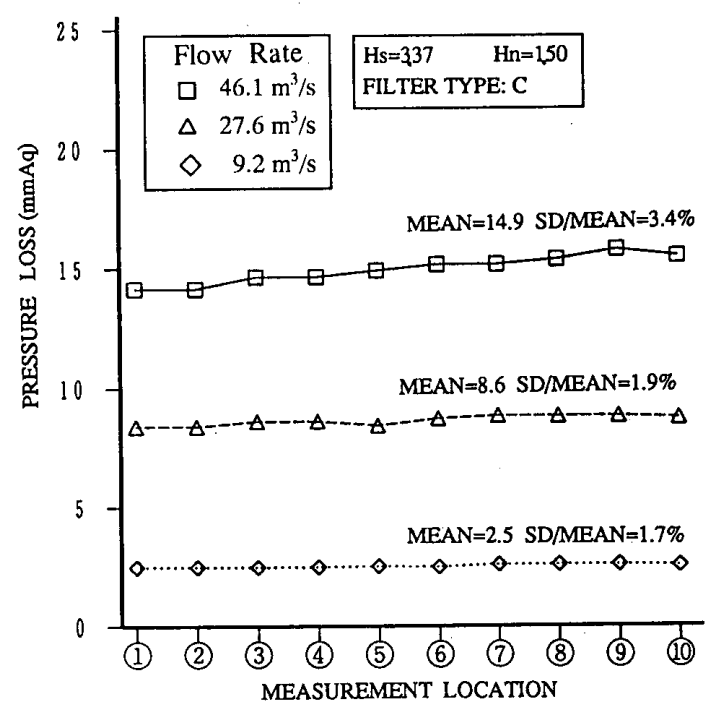

図4 $\mathrm{Hs}=3.37 、 \mathrm{Hn}=1.5 \mathrm{~m}$ の時の差压分布

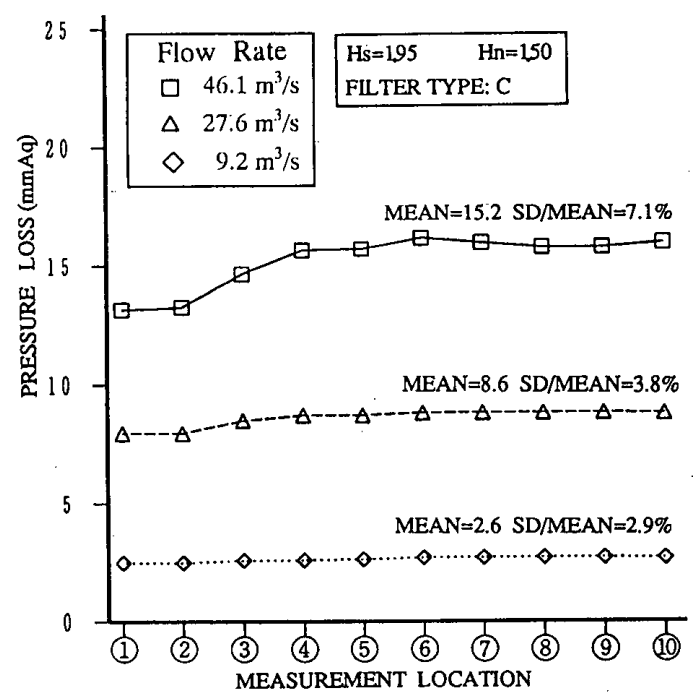

図5 $\mathrm{Hs}=1.95 、 \mathrm{Hn}=1.5 \mathrm{~m}$ の時の差压分布 
ぞれ35.3\%、21.0\%に達している。

実験の結果、天井チャンバの高さとノズルからの吹出 し風速は気流の均一性に大きく影響を及ばすことがわ かった。特に、吹出し風速を大きくするとノズル付近で の差王が極端に低下している。これはネック風速により 誘引が生じたためと考えられる。なお、図5および艮6を みると、天井チャンバの高さが十分でない場合でも、吹 出し風速が小さければ十分均一な気流が得られることが わかる。

\section{3. 気流の均一性に関する数值解析 3.1 数值解析の概要}

クリーンルーム内気流の数值解析に関しては、グ レーチングなど計算格子よりも小さな障害物に対し、セ ル内での流体占有率の変化扩よびそれによる圧力損失の 双方を考慮するアプローチ7)と、運動量方程式にのみ圧力 損失の効果を付加するアプローチ4)とがこれまでに提案さ れている。フィルタメディアのような障害物を対象とす

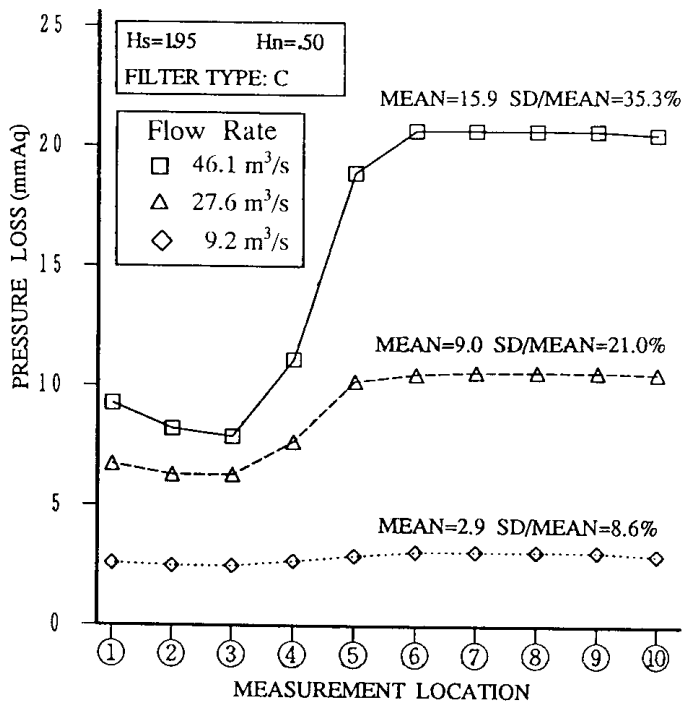

図6 $\mathrm{Hs}=1.95 、 \mathrm{Hn}=0.5 \mathrm{~m}$ の時の差压分布
る場合には、压力損失のみを考慮すればよいと考えられ、 ここでは運動量方程式のソース項としてフィル夕特性を モデル化した。

なお、Sadjadiら ${ }^{4)}$ 手法では、フィル夕の压力損失を定 数 $(0.5$ in Aq) としてソース項に与えた。しかし、図 2 に示し たように压力損失が面風速によって変化するので、压力 損失を固定值にしてしまうと、風速分布の均一性を適切 に評価することが困難である。本研究では、風速による 圧力損失の変化を考慮して、ソース項を与えた。

解析対象は天井チャンバおよび床下チャンバを含めた クリーンルーム系の全体として、k氏型 2 方程式乱流モデ ル8)9)用いて3次元の流れ場を解析した。基礎方程式を 以下に示す。

$\frac{\partial u_{i}}{\partial x_{i}}=0$

$\frac{\partial u_{i}}{\partial t}+\frac{\partial u_{i} u_{j}}{\partial x_{j}}=-\frac{\partial}{\partial x_{i}}\left(\frac{p}{\rho}+\frac{2}{3} k\right)+\frac{\partial}{\partial x_{i}}\left\{v_{t}\left(\frac{\partial u_{i}}{\partial x_{j}}+\frac{\partial u_{j}}{\partial x_{i}}\right)\right\}+S$

$\frac{\partial k}{\partial t}+\frac{\partial k u_{j}}{\partial x_{j}}=\frac{\partial}{\partial x_{j}}\left(\frac{v_{t}}{\sigma_{k}} \frac{\partial k}{\partial x_{j}}\right)+v_{t} G_{s}-\varepsilon$

$\frac{\partial \varepsilon}{\partial t}+\frac{\partial \varepsilon u_{j}}{\partial x_{j}}=\frac{\partial}{\partial x_{j}}\left(\frac{v_{t}}{\sigma_{\varepsilon}} \frac{\partial \varepsilon}{\partial x_{j}}\right)+C_{1} \frac{\varepsilon}{k} v_{t} G_{s}-C_{2} \frac{\varepsilon^{2}}{k}$

$v_{t}=C_{D} \frac{k^{2}}{\varepsilon}$

ここで、

$$
\begin{aligned}
G_{s} & =\left(\frac{\partial u_{i}}{\partial x_{j}}+\frac{\partial u_{j}}{\partial x_{i}}\right) \frac{\partial u_{i}}{\partial x_{j}} \\
\sigma_{k} & =1.0, \sigma_{\varepsilon}=1.3, C_{D}=0.09, C_{1}=1.44, C_{2}=1.92
\end{aligned}
$$

(2)〜(6)式の離散化にはコントロールボリューム法を用 いた。移流項にはQUICK法 ${ }^{10)} 、$ 拡散項には中心差分法を

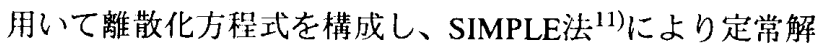
を求めた。

計算に用いたメッシュ分割を図7に示す。分割数はケー スによって異なるが、 $113 \times 24 \times 47$ から $113 \times 24 \times 54$ の のを用いた。給気ノズルの位置はメッシュ幅を $10 \mathrm{~cm} 、 そ$ の他の部分では $20 \mathrm{~cm}$ 等間隔とした。
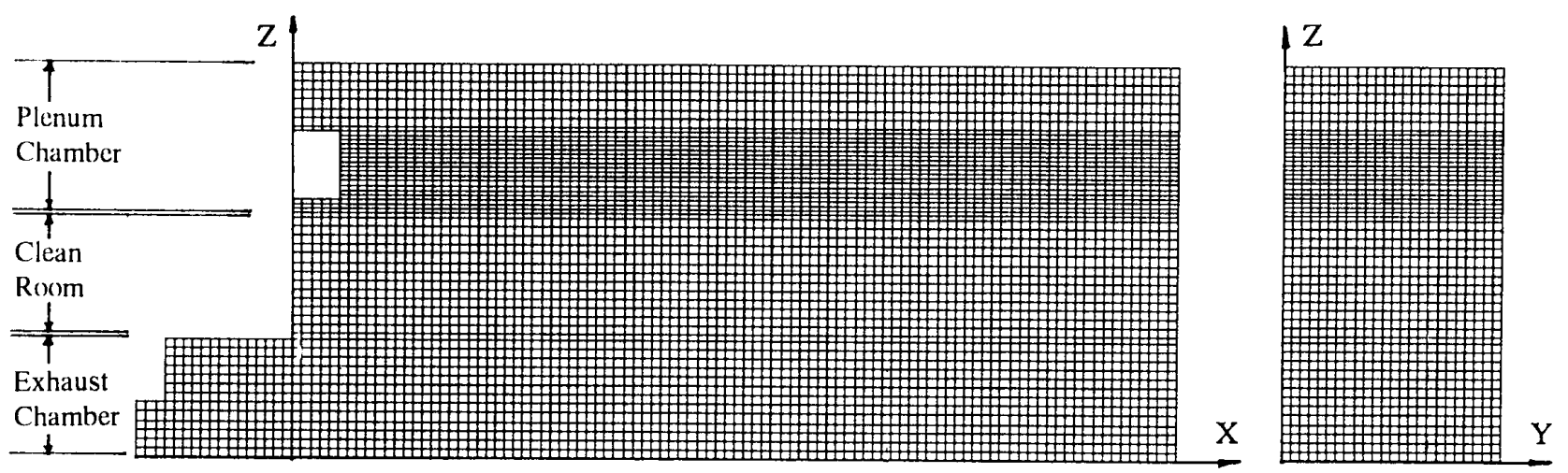

図7解析に用いたメッシュ分割 


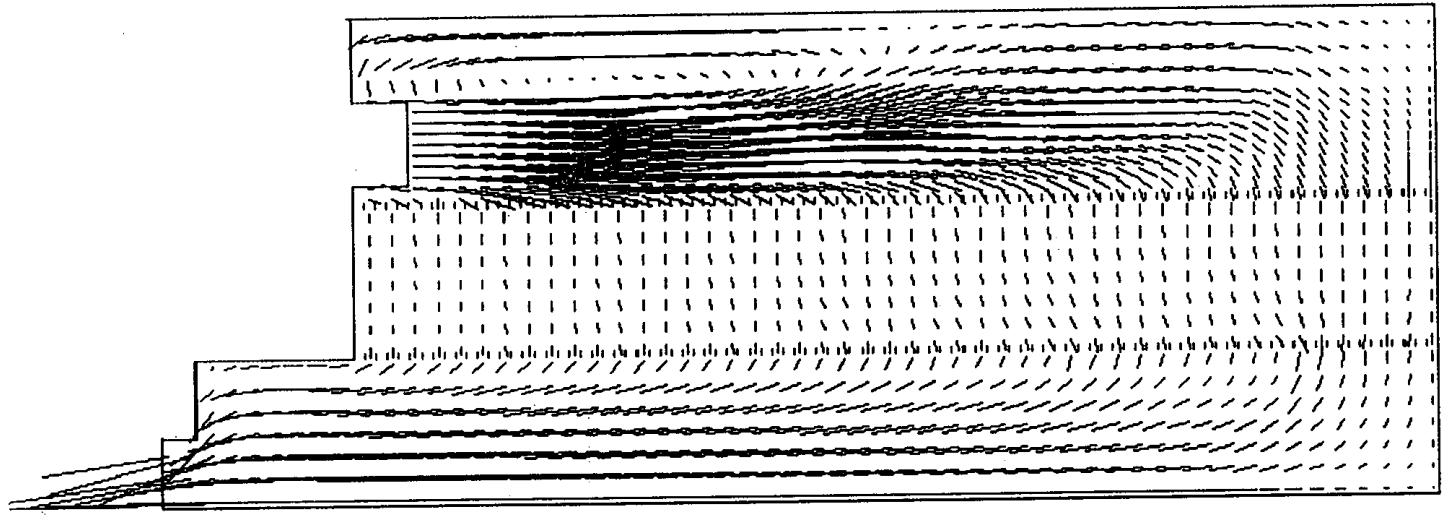

図8 風量 $46.1 \mathrm{~m}^{3} / \mathrm{s} 、 \mathrm{Hs}=3.37 、 \mathrm{Hn}=1.5 \mathrm{~m}$ の時の風速べクトル(1)

境界条件として壁面には対数則を、また天井チャンバ への給気ノズルには流入速度Un、乱流エネルギー $\mathrm{k} 〔 \mathrm{k}=$

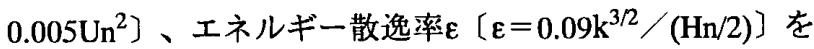
それぞれ固定值として与えた。

(3)式におけるソース項Sは、流体セルについて $\mathrm{S}=0$ 、 フィルタまたはグレーチング床を含むセルでは圧力損失 の効果を考慮して、次式のように表わした。

$$
\begin{aligned}
& \mathrm{S}=\Delta \mathrm{p} / \Delta \mathrm{z} \\
& \Delta \mathrm{p}=-A \mathrm{w}^{\mathrm{n}}
\end{aligned}
$$

フィルタに関しては、図2の実験結果から、 $\mathrm{n}=1 、 \mathrm{~A}=$ 245を用いた。

グレーチング床に関しては、開口部での圧力損失の場 合と同様に、 $\mathrm{n}=2$ である。これについては老川ら ${ }^{12)}$ の測 定によっても実証されている。また、同测定によると、 グレーチング床の開口率が50\%の時に、A=1となる。

\section{2 数值解析結果と実験結果との比較}

チャンバへの供給風量および天井チャンバ、給気ノズ ルの高さを次のように組合せた場合について数值解析を 行った。即ち、

(1) 供給風量 $46.1 \mathrm{~m}^{3} / \mathrm{s} 、 \mathrm{Hs}=3.37 \mathrm{~m} 、 \mathrm{Hn}=1.5 \mathrm{~m}$

(2) 供給風量 $46.1 \mathrm{~m}^{3} / \mathrm{s} 、 \mathrm{Hs}=1.95 \mathrm{~m} 、 \mathrm{Hn}=1.5 \mathrm{~m}$

(3) 供給風量 $46.1 \mathrm{~m}^{3} / \mathrm{s} 、 \mathrm{Hs}=1.95 \mathrm{~m} 、 \mathrm{Hn}=0.5 \mathrm{~m}$

(4) 供給風量 $27.6 \mathrm{~m}^{3} / \mathrm{s} 、 \mathrm{Hs}=1.95 \mathrm{~m} 、 \mathrm{Hn}=0.5 \mathrm{~m}$

図8にケース(1)の解析結果を風速のベクトル分布として 示し、また図9にノズル付近の領域を拡大して示している。 ただし、図8では図を見やすくするため、X方向とZ方向 のベクトルを1本おきに間引いて示してある。クリーン ルーム空間においては、ほぼ全面的に下降流を形成して おり、かつ均一な気流分布を示している。

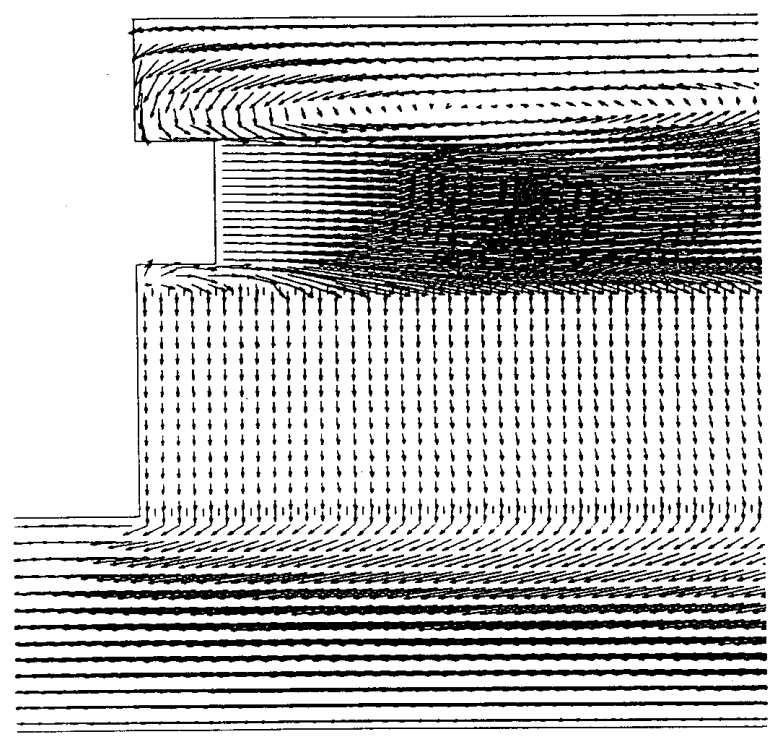

図9 風量 $46.1 \mathrm{~m}^{3} / \mathrm{s} 、 \mathrm{Hs}=3.37 、 \mathrm{Hn}=1.5 \mathrm{~m}$ の 時の風速ベクトル(2)

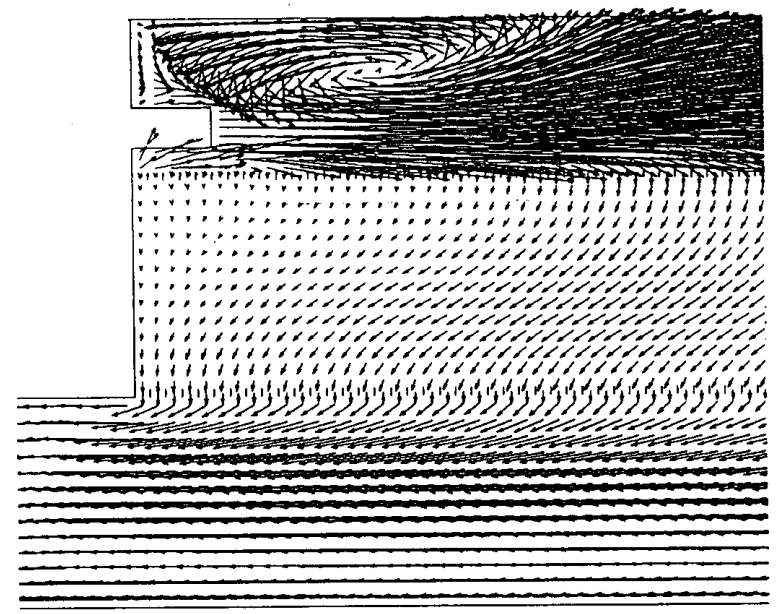

図10風量 $46.1 \mathrm{~m}^{3} / \mathrm{s} 、 \mathrm{Hs}=1.95 、 \mathrm{Hn}=0.5 \mathrm{~m}$ の 時の風速ベクトル 


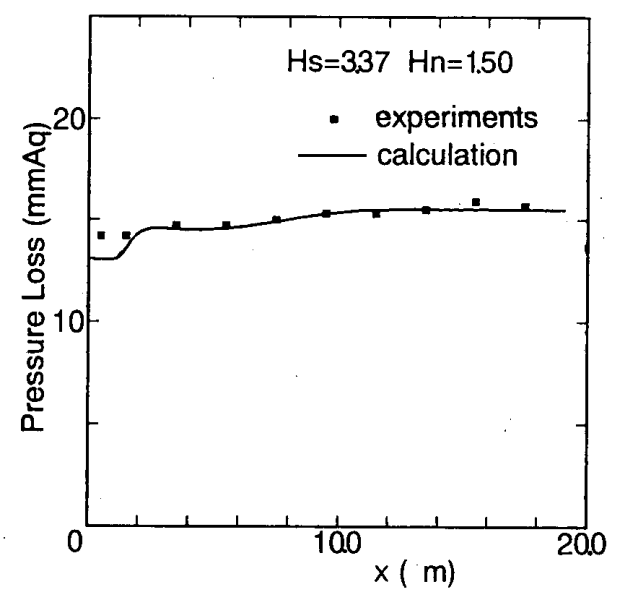

図11 風量 $46.1 \mathrm{~m}^{3} / \mathrm{s}$ の時の計算值之実験值との比較

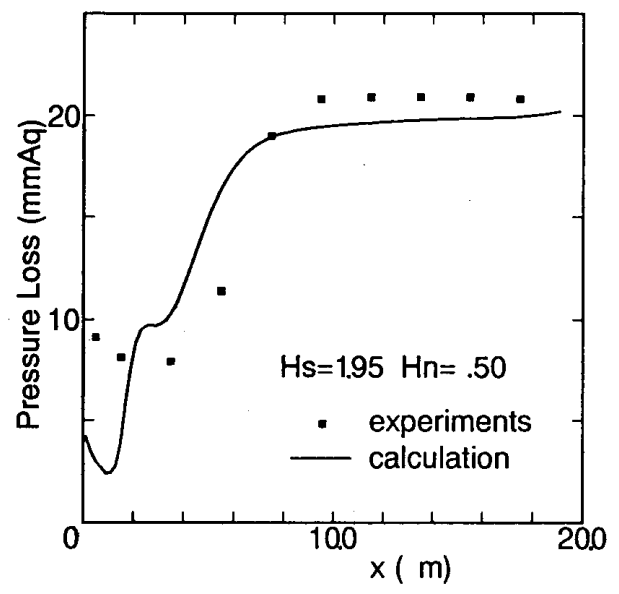

図13 風量 $46.1 \mathrm{~m}^{3} / \mathrm{s}$ の時の計算值と実験値との比較

Hs之Hn両方とも小さいケース(3)の解析結果を図10に示 す(ノズル付近の拡大図)。天井チャンバの左上では旋回流 が形成されること、ノズルの直下では誘引が生じて、 フィルタを通過する風速がばらつくことが解析によって 再現された。このため、クリーンルーム空間での気流分 布がケース(1)に比へかなり不均一となっている。

ケース(1)〜(4)の解析結果を、フィル夕の上下面での差 殴分布としてまとめたものを図11〜14に示す。前述した 実験結果を比較のため併記した。

いずれの場合も、数值解析により求めた差圧分布は実 験結果と定量的に一致しており、全体的な傾向からも解 析結果が実際の現象をよく再現していることがわかる。 このことから、本研究で提案した数值解析手法を用いて 気流の均一性を検討することは十分可能と考えられる。 ただし、吹出し風速の大きい図13の条件で特に顕著なよ うに、ノズルに近い部分での差圧分布には実験值との差 異が認められる。その原因については、乱流モテルを含 めて詳細な検討の余地はあるが、本研究では全体的な傾 向に着目しており、局所的な差異は実用的にそれほど大 きな支障がないと考える。

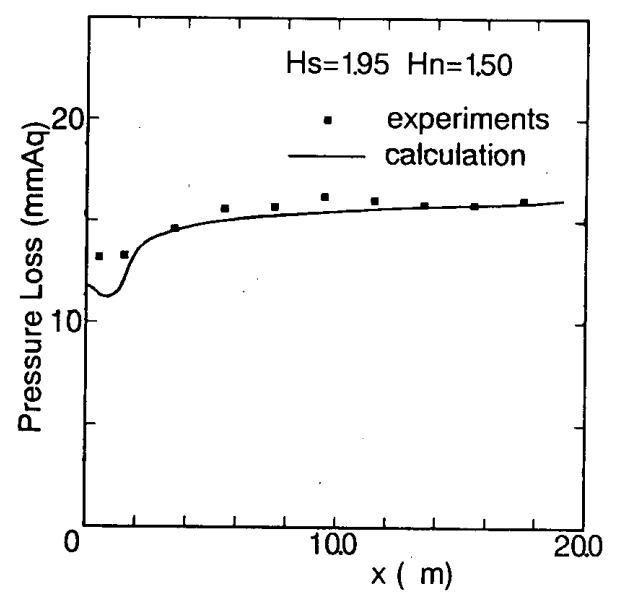

図12 風量 $46.1 \mathrm{~m}^{3} / \mathrm{s}$ の時の計算値と実験値との比較

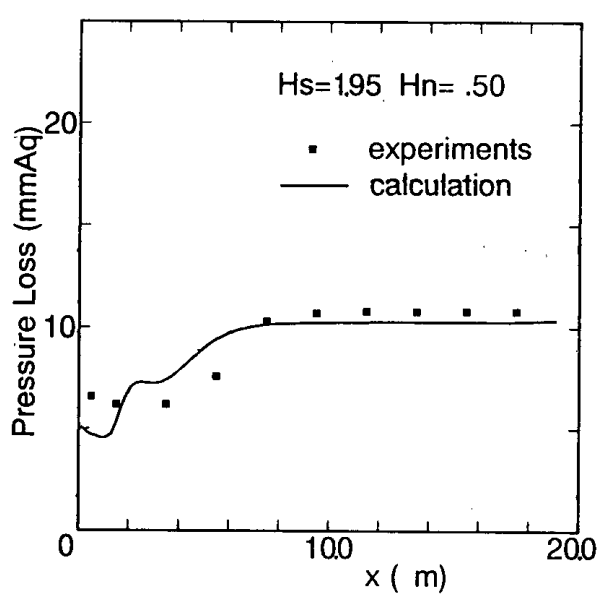

図14 風量 $27.6 \mathrm{~m}^{3} / \mathrm{s}$ の時の計算值と実験值との比較

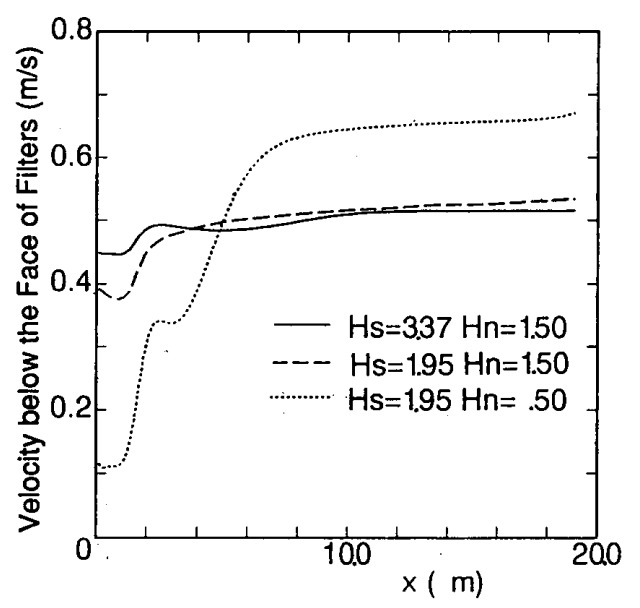

図15 フィルタ面直下の風速分布(風量 $\left.46.1 \mathrm{~m}^{3} / \mathrm{s}\right)$

なお、図15は、図11〜図13と同様の条件についての数 值解析結果を、フィルタ面直下における風速の分布とし てまとめたものである。当然のことながら、差圧分布と 風速分布亡は傾向的によく一致している。このことから 屯、差圧分布によって風速の均一性を評価することの妥 当性が確認された。 
表1 Hn、UnとSD/ $\overline{\mathrm{U}}_{\mathrm{f}}$ との関係

\begin{tabular}{|c|c|c|c|c|}
\hline $\begin{array}{c}\mathrm{Hn} \\
(\mathrm{m})\end{array}$ & $\begin{array}{c}\mathrm{Un} \\
(\mathrm{m} / \mathrm{s})\end{array}$ & $\begin{array}{c}\overline{\mathrm{U}}_{\mathrm{f}} \\
(\mathrm{m} / \mathrm{s})\end{array}$ & $\begin{array}{c}\mathrm{SD} \\
(\mathrm{m} / \mathrm{s})\end{array}$ & $\begin{array}{c}\mathrm{SD} / \overline{\mathrm{U}}_{\mathrm{f}} \\
(\%)\end{array}$ \\
\hline 1.0 & 12.8 & 0.5 & 0.3 & 14.6 \\
\hline 1.2 & 10.7 & 0.5 & 0.054 & 10.8 \\
\hline 1.5 & 8.6 & 0.5 & 0.040 & 8.0 \\
\hline 1.7 & 7.5 & 0.5 & 0.036 & 7.2 \\
\hline 2.0 & 6.4 & 0.5 & 0.028 & 5.6 \\
\hline 2.2 & 5.8 & 0.5 & 0.023 & 4.6 \\
\hline 2.5 & 5.1 & 0.5 & 0.020 & 4.0 \\
\hline
\end{tabular}

\section{4. 吹出し風速と天井チャンバ高さの適正值の検討}

対象としたクリーンルームについての気流の均一化を 目的として、ノズルからの吹出し風速および天井チャン バ高さの適正值の算定を試みた。

模型実験および数值解析の結果から、フィルタ面にお いてより均一な気流分布を得るためには、天井チャンバ 高さを大きくとり、かつノズルからの吹出し風速を小さ く抑えることが有効と考えられる。しかし建設コストな どの面からはチャンバの高さを適当な範囲に抑えること が要求されるため、チャンバの高さを増大させない方向 で風速の均一化を考えていく必要がある。そこで、まず フィルタ面での風速の均一化を考慮してノズルからの吹 出し風速の適正值を決定し、これに見合うノズルの高さ $\mathrm{Hn}$ と施工・メンテナンス作業に必要な余裕高さ $\alpha$ の和と して、チャンバの高さ $\mathrm{Hs}(\mathrm{Hs}=\mathrm{Hn}+\alpha)$ を求めていく方法 が現実的と考えられる。

ここでは供給風量を $46.1 \mathrm{~m}^{3} / \mathrm{s} 、 \alpha を 0.5 \mathrm{~m}$ 固定してHnを 変化させ、それぞれの場合について数值解析を行い フィルタ面での風速の均一性を比較した。解析により得 られた結果を表1に示す。 Hnを大きくすると、風速のば らつき $\left(\mathrm{SD} / \overline{\mathrm{U}}_{\mathrm{f}}\right)$ は単調に減少している。この関係を、ノズ ルからの吹出し風速Unと $\mathrm{SD} / \overline{\mathrm{U}}_{\mathrm{f}}$ との関係として整理した ものを図16に示す。両者はほぼ比例関係にあると認めら れ、ここで対象としたクリーンルームについて係数を求 めると次式が成り立つ。即ち、

$$
\mathrm{SD} / \overline{\mathrm{U}}_{\mathrm{f}}(\%)=1.35 \mathrm{Un}-3.1
$$

したがって、フィルタ面における風速のばらつきを 10\%以内に抑えるためにはUnを $10 \mathrm{~m} / \mathrm{s}$ 以下 $(\mathrm{Hn} \geqq 1.3 \mathrm{~m}) 、 \mathrm{Hs}$ を1.8m以上に、また、ばらつきを5\%以内に抑えるために はUnを $6 \mathrm{~m} / \mathrm{s}$ 以下 $(\mathrm{Hn} \geqq 2.1 \mathrm{~m}) 、 \mathrm{Hs}$ を $2.6 \mathrm{~m}$ 以上にする必要の あることが算定できる。

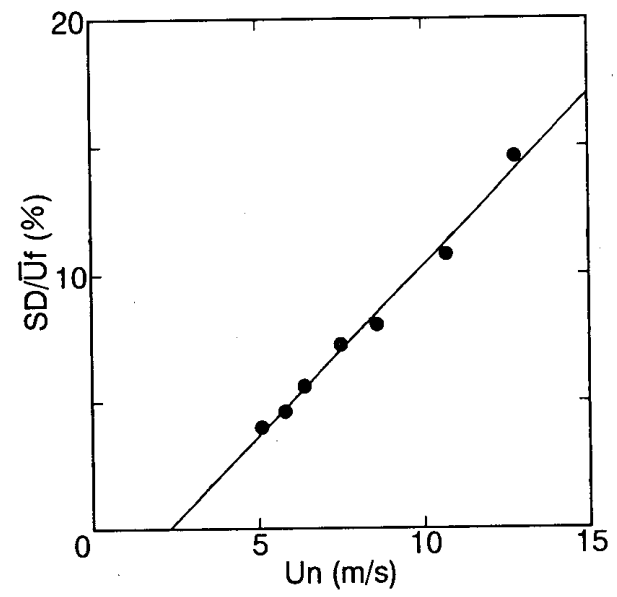

図16 フィルタ直下気流分布のばらつきと ノズル吹出し風速Unとの関係

\section{5. まとめ}

本研究では、天井チャンバ方式のクリーンルームを対 象として、気流の均一性について実験および数值解析に よる検討を行った。また、その結果をもとにチャンバ構 造や吹出し風速の適正化を試みた。得られた主な成果を 以下にまとめる。

(1) フィル夕面での風速の均一性は、天井チャンバの高さ およびチャンバへの吹出し風速によって変化する。 チャンバの高さは大きいほど、また吹出し風速は小さ いほど均一な気流分布が得られる。

(2) フィルタの圧力損失を考虑した数值解析手法を提案し、 チャンバの高さ、吹出し風速および供給風量をパラ メータとした試行解析を行った。実験值と比較した結 果、本解析手法によりクリーンルーム内の気流の均一 性を定量的に予湘できることがわかった。

(3) 数値解析手法を用いて天井チャンバとノズル寸法の適 正值を検討し、フィル夕面で均一な気流分布を得るた めのクリーンルーム設計法を提案した。

(4) フィル夕面での風速のばらつきとノズル吹出し風速と はほぼ比例関係にあることを見出した。この関係から、 風速のばらつきを特定の範囲に抑えるために必要なノ ズル寸法を算定できることがわかった。

本報ではクリーンルームの上流側である天井チャンバ について気流の均一化を検討した。今後は、クリーン ルーム内の設備レイアウトや床面・床下チャンバの設計 法についても検討していく必要がある。

\section{謝辞}

本研究を進めるにあたっては、椒大林組の諏訪好英氏 亚びに片岡浩人氏には数多くの有益なる御助言をいただ き、また実験に際して、同社の渥美勝利氏には多大なご 協力をいただき、ここに記して感謝の意を表します。 
記号

A ： 压損と流速の関係を表わす保数

$\mathrm{C}_{1}, \mathrm{C}_{2}, \mathrm{C}_{\mathrm{D}}$ ： k飞乱流モデルにおける係数

$\mathrm{Hn}$ ： 給気ノズルの高さ

[m]

$\mathrm{Hs}$ ： 天井チャンバの高さ

[m]

n ： 压損と流速の関係を表わすべキ指数

$\mathrm{n}_{\mathrm{c}}$ ：模型の抵抗俰数之実物の抵抗係数の比

$\mathrm{n}_{\mathrm{u}}$ ： 模型の流速と実物の流速の比

$\mathrm{p}$ : 欧力

$\triangle \mathrm{p}$ : 欧力差

SD：標準偏差

Un：ノズルからの吹出し風速

$\left[\mathrm{N} / \mathrm{m}^{2}\right],[\mathrm{mmAq}]$

$\mathrm{U}_{\mathrm{f}}$ : フィル夕直下の風速 $[\mathrm{m} / \mathrm{s}],[\mathrm{mmAq}]$

$\overline{\mathrm{U}}_{\mathrm{f}}$ ：フィル夕直下の平均風速

$[\mathrm{m} / \mathrm{s}]$

$u_{i}:$ 速度の 3 成分

u : $\mathrm{x}$ 方向の速度

$\mathrm{v}: \mathrm{y}$ 方向の速度

$\mathrm{w}$ ： $\mathrm{z}$ 方向の速度

$\alpha$ : $\mathrm{Hs}$ 之Hnの差

$\mathrm{k}$ ： 乱流エネルギー

$\varepsilon \quad:$ エネルギー散逸率

$v_{\mathrm{t}} \quad$ : 渦動粘性係数

$\rho$ : 流体密度

$\sigma_{\mathrm{k}}, \sigma_{\varepsilon} ： k \in$ 乱流モデルにおける係数

\section{参考文献}

1) 前田、竹浪、田中：クリーンルーム内の気流適正化 に関する研究（第 1 報）、第 5 回空気清净とコンタ ミネーションコントロール研究大会、p.115 118、 1986.4

2) 田中、前田、斎木：クリーンルーム内の気流適正化 に関する研究（第 2 報）、第 5 回空気清浄とコンタ ミネーションコントロール研究大会、p.119～122、 1986.4

3) 高橋、伊藤、岡田：垂直層流型クリーンルームの形 状と気流分布の不均一度、第 8 回空気清净とコンタ ネーションコントロール研究大会、p.233〜237、 1989.4

4) Sadjadi, R.S.M. and Liu, B.Y.H.: Supply Plenum and Airflow Uniformity in Cleanrooms, J. of the IES, March/April 1991

5) 勝田、土屋 : 室内空気分布の模型実験に関する研究、 第1 報〜第3 報、空気調和・衛生工学会論文集、No.17、 p. $1 \sim 28 、 1981.10$

6) 村上、加藤、孔、中川 : 大架構建築内の温熱 - 空気 環境に関する研究、模型実験による予測法、生産研 究、東京大学、39巻9号、p.361 370、1987.9

7) 鈴木、村上、加藤、ロンダー：グレーチング纴力損 失のk-モの影響を考慮した改良型2方程式モデル、空 気調和・簿生工学会学術講演会講演論文集、p.717 720、 1988.9

8) Lauder, B. E. and Spalding, D. B.: Mathematical models of turbulence, Academic Press, Londón and New York, 1972

9) 野村、村上、加藤、佐藤 : 3 次元乱流数值解析之模型 実験、数值解析手法を用いる室内空気分布予測法に 関する研究、その2、日本建築学会論文報告集、 No.298、 1980.12

10) Leonard, B. P.: The QUICK algorithem: A uniformity thirdorder finite-difference method for convective flows, Computer Method in Fluids, Pentech Press, 1980

11) Patankar, S. V.: Numerical heat transfer and fluid flow, McGraw-Hill, New York, 1980

12）老川、鈴木、梶間、加瀬：クリーンルーム内の流れ を考慮した室圧調整、第7回空気清浄とコンタミネー ションコントロール研究大会、p.89〜92、1988.4

(1993 年 9 月 8 日原稿受理, 1994 年 1 月 31 日採用決定) 